\title{
Application of GIS technology in the analysis of wolf Canis lupus L. behaviour and migration routes in the landscape
}

\author{
Mateusz Kulik, Dariusz Kamiński
}

\begin{abstract}
Nicolaus Copernicus University, Faculty of Biology and Environmental Protection, Chair of Geobotany and Landscape Planning, Lwowska 1, 87-100 Toruń, Poland, e-mail:matik911@wp.pl,daro@umk.pl
\end{abstract}

\begin{abstract}
The paper presents the results of tracking a pack of wolves carried out between January and February 2013 in the Forest Division of Solec Kujawski in Bydgoszcz Forest, which surrounds three cities - Bydgoszcz, Torun and Solec Kujawski, and locally encroaches on their administrative areas. The behaviour of wolves and their migration routes were determined based on tracks left on snow. The location of tracks was recorded with a GPS receiver. Visualization and data analysis were performed with the software QuantumGIS. The pack consists of seven wolves and one, most likely rejected male following the close group. A total of $10.22 \mathrm{~km}$ of trails, including characteristic ground scratching, faeces and a prey killed by the wolf pack, were found on the snow over an area of ca. $100 \mathrm{~km}^{2}$. Forest roads are preferred landscape elements of the monitored pack, used for movement. Data analysis with GIS tools helps to determine the migration routes and behaviour of the wolf pack living in the study area.
\end{abstract}

Keywords: wolf, Solec Kujawski Forest Division, Bydgoszcz Primeval Forest, GIS, pack, territory, tracks.

\section{Introduction}

Wolves returned to Bydgoszcz Primeval Forest in 2004 after their absence lasting since 1989 when a male wolf was shot in the Forest Division of Cierpiszewo. They probably migrated along the north or north-central corridor (Kamiński et al. 2011), and first arrived in the western part of the Forest - their tracks were observed in the Forest Division of Solec Kujawski and in the western part of the Forest Division of Cierpiszewo (Krzemien 2008 after Sewerniak 2010). The objective of this paper was to analyse the migration routes of the Canis lupus pack and to investigate the behaviour of the tracked animals. The observations covered the wolf population living in the area of the Solec Kujawski Forest Division. So far no methodological observations have been carried out on the pack of wolves; only the number of animals was known (Kamiński et al. 2011). Observations of the wolf pack living in the areas of neighbouring Forest Divisions - Cierpiszewo and Gniewkowo - are conducted by Sewerniak (2010).

\section{Study area}

The research was conducted in the Forest Division of Solec Kujawski situated in the central part of Bydgoszcz Forest and the Kujawy-Pomerania province, in the part located in the district of Bydgoszcz - the town and the commune of Solec Kujawski, and the commune of Nowa Wieś Wielka. Two big cities are located within a distance of several kilometres from the Solec Kujawski Forest Division: Bydgoszcz $(18 \mathrm{~km})$ and Torun $(35 \mathrm{~km})$. The town of Solec Kujawski, with the headquarters of the Forest Division, is located directly to the north of the forest complex.

The study area was formed after the last glaciation and is situated in the Torun Basin and the Inowrocław Plain (Kondracki 2000). The whole area of Bydgoszcz Forest is included in the Protected Landscape Area "Dunes of the Torun-Bydgoszcz Basin". The range of the wolf pack covers also the Łażyn Nature Reserve, which includes the oldest primeval pine forest stands. The undulating land relief is characterized by relative height differences of up to 
30-40 m (Kamiński et al. 2011). The association of Peucedano-Pinetum (fresh pine forest) dominates and covers ca. $70 \%$ of the forest area; the mixed coniferous forest of Querco roboris-Pinetum covers $10 \%$ of the area.

\section{Research methods}

The behaviour of wolves and their migration routes were determined based on tracks left on snow. This method is an effective tool to study populations of large predators (cf. Patterson et al. 2004; Jędrzejewski et al. 2010). The fieldwork and data analysis were conducted with the use of GIS tools. The research was conducted between late January and early February during three days (three field trips): on 31th January, 15th February and 27th February 2013. The field reconnaissance, practical principles of tracking and identification of animal trails were conducted during the first field trip. Approximately $100 \mathrm{~km}^{2}$ were investigated, each route three times. After wolf traces were found, the trails were followed on foot. The location of wolf tracks in the field was recorded using a GPS receiver in the shape file created in the software ArcGIS for Windows Mobile. Also photographic documentation was completed for each field trip. In addition, information provided by employees of the Solec Kujawski Forest Division was used in the presented paper.

The results were processed with the software QuantumGIS which visualized the preferred migration routes of wolves. The investigated home range was accounted for in the analysis; points were connected into transects based on the continuity of trails left by Canis lupus. Their length was measured using the QGIS tools in order to determine the landscape type of wolf pack migrations. The Microsoft Office Excel 2007 spreadsheet was used to create graphs and to perform calculations.

\section{Results}

\subsection{Analysis of wolf behaviour}

The presence of seven wolves was determined in the course of the research. It is likely, however, that the compact pack of wolves is followed by a rejected two-year male wolf, which is the eight individual living in the study area (Fiderewicz 2013 - personal communication). The male was observed near a pile of beets put out for the game every winter.

During the first field trip, the wolves were tracked in two places: in the central part of the study area, where tracks were found along a distance of $1 \mathrm{~km}$, and in the south-western part along three smaller sections: $0.13 \mathrm{~km}$; 0.34 and $0.35 \mathrm{~km}$ (Fig. 1). The longest trail ran along the forest road between the edge of the forest and the forest clearing located near the

Broadcasting Centre of Polskie Radio Program I, on a former military ground in the village of Kabat. Furthermore, the trails of wolves following the roe deer's trails were tracked and many characteristic scratching traces were recorded. In the woodlots on a small elevation, wolf's faeces were found (whitish scat with fragments of fur and bones).

At night of 13th/14th February or in the morning 14th February, the pack of wolves killed a red deer (Cervus elaphus) calf, which was consumed for ca. 1.5 days. It appears that the prey was approached twice - the first time when it was killed and partly consumed, and the second time when the pack dragged it away and finished the consumption. The course of hunting was reconstructed following the tracks left on snow. The reconstructed (hypothetical) section was $3.6 \mathrm{~km}$ long (Fig. 1), two documented sections were $0.6 \mathrm{~km}$ and $2.2 \mathrm{~km}$ long. The wolves followed the red deer fawn in a southerly direction up to the woods where they finally killed and eaten up the prey. Traces of blood, a gnawed leg and partly digested intestinal content of the prey were found on the snow. Broken bones and skin were found in a forest plantation located within a distance of ca. $0.7 \mathrm{~km}$, where wolves apparently had moved the remains of the prey after they were found by employees of the Forest Division on February 14th, 2013, which was evidence by human footprints left on the snow. After consuming the prey, the wolves walked towards the older forest stands from where they continued trotting eastwards. After approximately $2 \mathrm{~km}$, they turned north and after 0.5 $1.0 \mathrm{~km}$ suddenly turned off to the north-west where most likely they took a rest in a young growth forest. On one of the roads, the wolf pack broke up - wolves were not trotting any longer and hence the animals were easily counted. The group consisted of 7 animals. About $2 \mathrm{~km}$ from the place where the fawn was killed, wolf trails and a fragment of an animal leg were found near the junction of forest roads, which probably came from a previously killed animal, taken by one of the pack's members (a wolf pup) as a "trophy". Young wolves often carry fragments of a hunted prey, e.g. legs, treating them as trophies-toys (Nowak $\&$ Mysłajek 2000). The presence of one-year old pups in the pack is evidenced by small wolf paw prints.

On the 15th of February 2013, a camera trap was installed by forest guards next to a calf skin left by wolves on a tree. The trap was activated every time a movement was registered by a photosensor. The camera was left in the forest for one day during which the wolves did not return to the abandoned skin.

During the third field trip, the length of trails was 4.8 $\mathrm{km}$ (Fig. 1). It was the longest wolf migration route found during the tracking. Paw prints were again found on the snow near the former German military training ground Ka- 


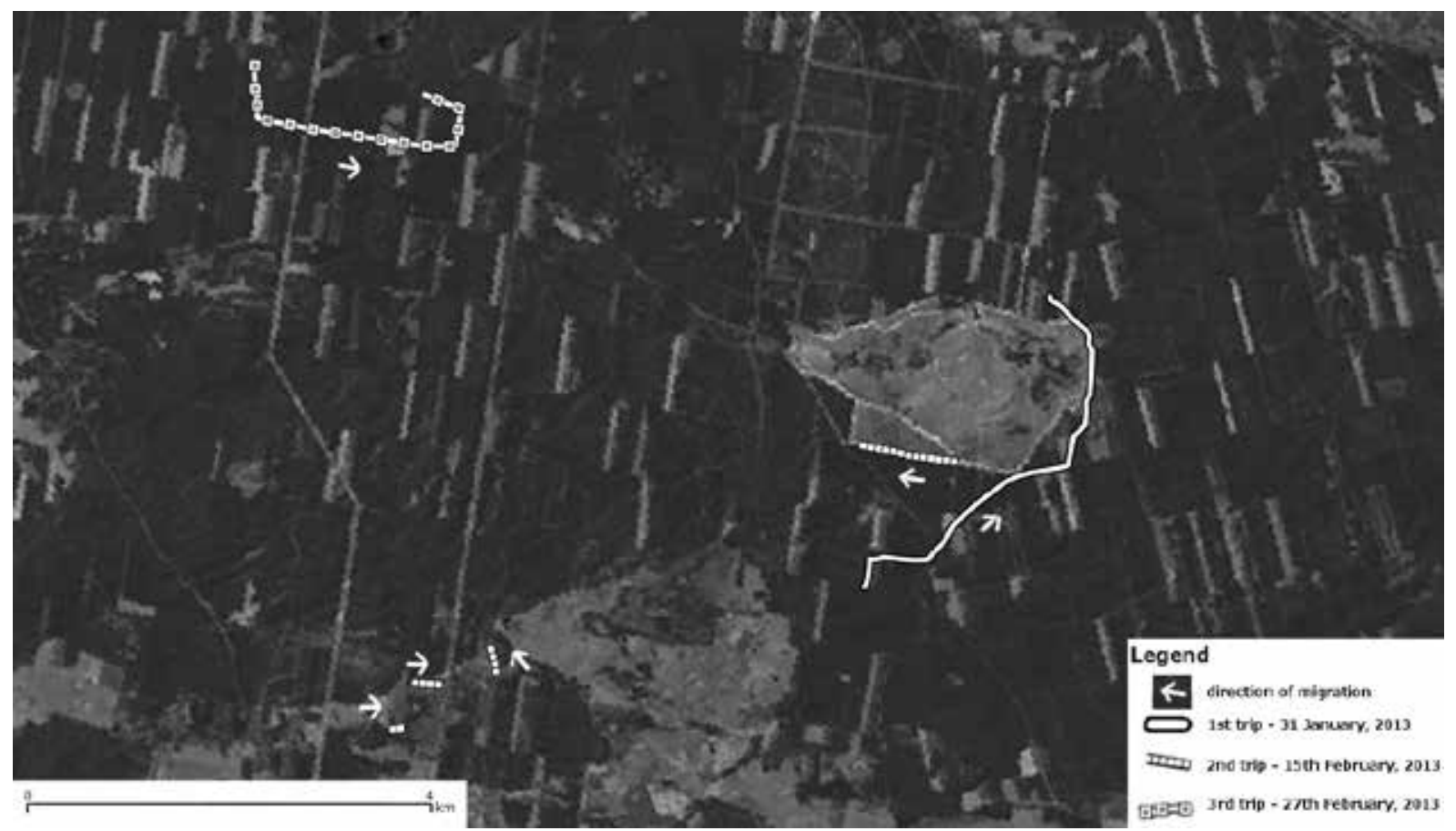

Figure 1. Migration routes of Canis lupus documented in the course of the research (map: Free Global Orthorectified Landsat Data - http://www.landsat.org/ortho/)

bat, but this time at its eastern end. The pack was moving in a northerly direction. At the beginning of the distance, traces of urination were found (probably left by a male or the $\alpha$ female), as well as ground scratching (characteristic territorial marking), and a place of snow bath taken by wolves. The trails branched in two directions - to the north and to the south.

\subsection{Analysis of Canis lupus migration in the landscape}

The length of all trails was $10.22 \mathrm{~km}$. Some of the trails ended near young forest stands, which most likely served as a central territory and a refuge of the wolf pack. In most cases, i.e. in $81.1 \%$, wolves moved along the forest roads, including $62.5 \%$ midforest roads and $18.6 \%$ of roads running along the edge of the forest and the forest clearing (Fig. 2). The remaining $18.9 \%$ was represented by a path of the wolf pack running through the forest and through open areas (places were the prey was consumed) $-18.1 \%$ and $0.8 \%$ respectively.

\section{Discussion}

The followed pack of wolves is one of the two wolf packs living in the Bydgoszcz Forest. It lives in forests situated within the limits of Bydgoszcz, Solec Kujawski and Cierpiszewo Forest Divisions. The second pack of wolves moves within the range of Cierpiszewo, Gniewkowo Forest Divisions (Fiderewicz 2013; Sewerniak 2013 - personal communication). In small fragments of the Cierpiszewo Forest Division, territories of the two wolf packs may overlap (Nowak \& Mysłajek 2011). As evidenced by the data analysis, the wolf population in the studied part of Bydgoszcz Forest (Fig. 3) consisted of 3-4 animals in 20042008, and 7-8 animals in the following years. The current size of the wolf pack is close to the size optimal for wolves living in the European forests of the temperate zone, where red deer and roe deer are their main food (Jędrzejewski et al. 2004).

The study area covers $100 \mathrm{~km}^{2}$, i.e. more than $1 / 3$ of the wolf pack's territory. Most likely it is the central part as several territorial marking traces were found in the area, including ground scratching and defecation typical of central territories located far from other packs of wolves, human communities and roads (Nowak 2013). The main role of marking is to defend the territory and mark the important points, so-called "hot-spots". The aforementioned marks 


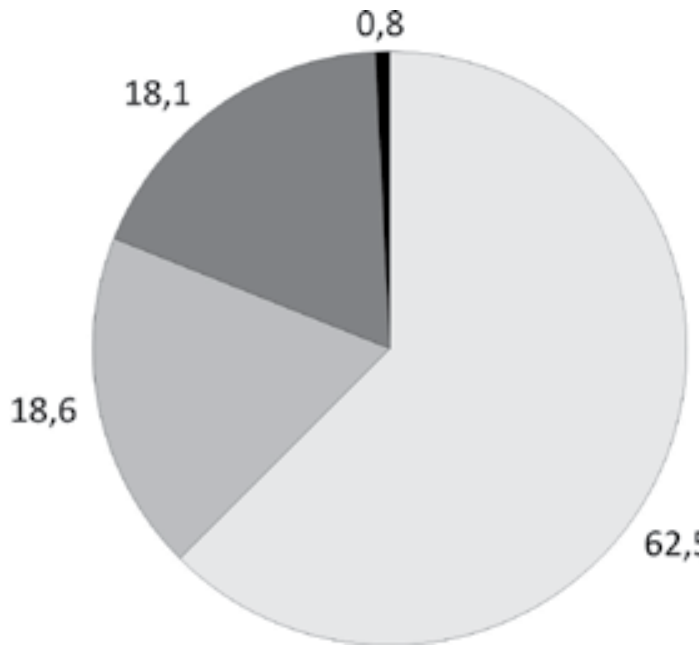

along midforest roads

along the edge of the forest and the forest clearing

through the forest

Figure 2. Percentage diagram of Canis lupus migration routes in the landscape (authors' data)

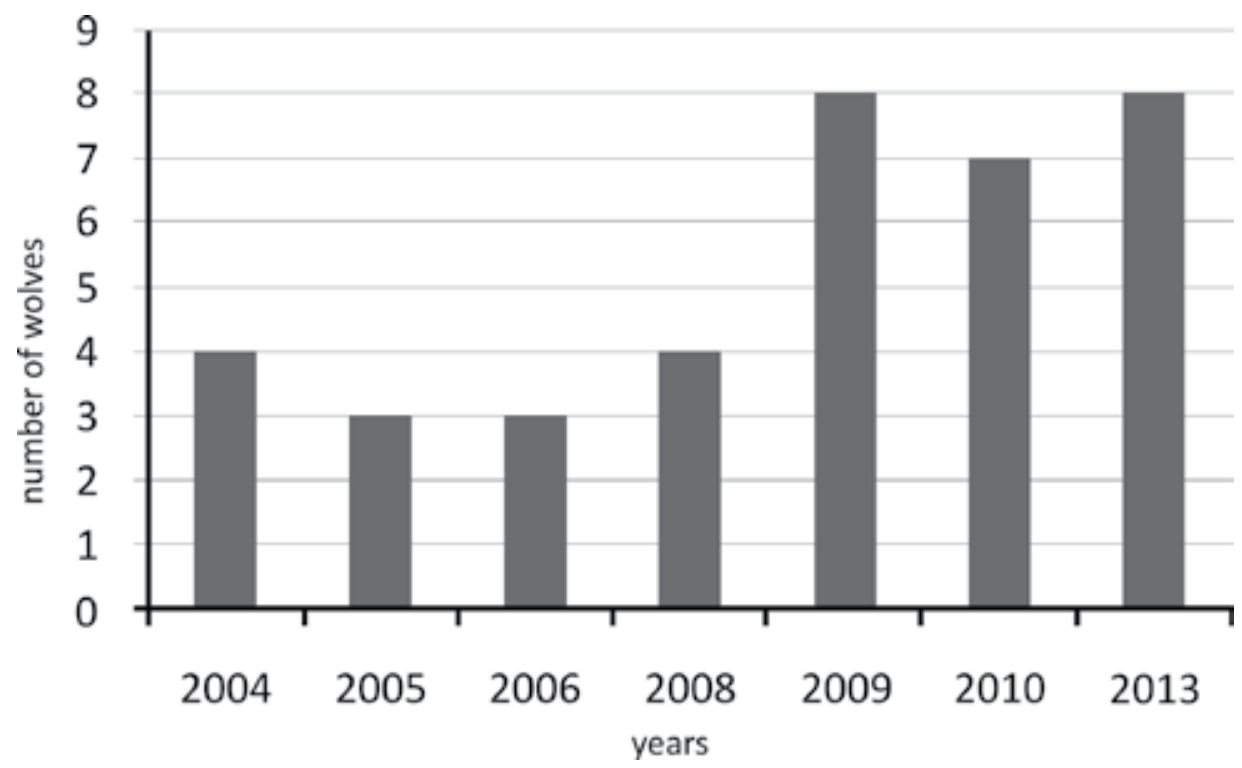

Figure 3. The size of the wolf pack (in the studied part of the Bydgoszcz Primeval Forest), after its return in 2004 (data from 2004-2010 yrs - after Kamiński et al. (2011); data from $2013 \mathrm{yr}$ - the authors' data)

are observed mostly in winter (October-March), particularly during the mating season (January-February). The research was conducted between late January and early February when territorial marking intensifies. Scratching the ground to mark the territory with urine scent is more common near the roads and intersections, whereas scat is often found in the woods. Similar behaviour has been observed among wolves in the Białowieża Primeval Forest (Zub et al. 2003). Scratching is a long-lasting sign which requires firm ground. Decision-making about marking a particular site is a peculiar strategy aiming at the balance between the effects achieved and the expenses incurred (Zub et al. 2003).
Branching of the trails observed on the third day of the fieldwork can be interpreted at least two different ways. The first possibility is the presence of one pack split into smaller subgroups inspecting the territory. The mating season of wolves starts in February and this involves an increased activity of the alpha pair, which often moves alone and intensively marks the territory (Nowak \& Mysłajek 2000). The second possibility is the existence of two packs of wolves within a short period of time over the same territory. The pack which smelled the scent left by the other group of wolves walked away to avoid entering the scentmarked area. 
The preferred landscape elements of the monitored pack of wolves are forest roads. The wolves use the existing routes and this helps them to reduce the energy spent on migrations in search of a prey. Places of their diurnal rest and preying are located in the woods not easily accessible, which increases the safety of the wolf pack. It is more difficult for the game ambushed by wolves to get away in the dense forest (Zub et al. 2003). The obtained results are consistent with observations performed in the Białowieża Primeval Forest, where wolves use forest roads more often than paths between forest stands (Zub et al. 2003). It has also been reported that packs of wolves prefer dense forest stands and use frozen rivers rather than forest roads (Musiani et al. 1998).

\section{Conclusions}

The following conclusions has been concluded on the basis of field observations and analysis of the source material (personal communication, articles quoted):

1. Two packs of wolves live in Bydgoszcz Forest. The tracked Canis lupus L. pack consisted of seven (several years old) animals and one rejected male wolf outside the group.

2. The total length of all six sections of wolf trails was $10.22 \mathrm{~km}$. The longest single section was $4.8 \mathrm{~km}$ and was located in close proximity of the Broadcasting Centre of Polskie Radio Program I.

3. For the observed Canis lupus pack, forest roads are the preferred element of the landscape for move.

4. The pack is breeding and hence stable. The last reproduction took place in 2012.

5. The described wolf pack marked the territory with scat and characteristic ground scratching.

6. The GIS analysis provided more comprehensive information on migration routes and behaviour of the wolf pack living in the Forest Division of Solec Kujawski.

\section{Acknowledgements}

We are grateful to the Forest Division Manager MSc Eng. Jakub Siedlecki and the whole team of the Solec Kujawski Forest Division for the opportunity to pursue this study. Special words of gratitude are addressed to Eng. Jan Fiderewicz for his assistance in arduous and time-consuming field observations.

\section{References}

Jędrzejewski W., Schmidt K., Jędrzejewska B., Theuerkauf J., Kowalczyk R. \& Zub K., 2004, The process of a wolf pack splitting in Białowieża Primeval Forest, Poland, Acta Theriologica 49: 275-280.

Jędrzejewski W., Borowik T. \& Nowak S., 2010, Wilk Canis lupus [Wolf Canis lupus], [in:] M. Makomaska-Juchiewicz (ed.) Monitoring gatunków zwierząt: Przewodnik metodyczny, Część 1 [Monitoring of Animals: Methodical Guide, Part I], GIOŚ, Warszawa: 297-318,

Kamiński B., Fiderewicz J. \& Grajewski S., 2011, Wilk (Canis lupus L.) w Puszczy Bydgoskiej i jego wpływ na populacje dziko żyjących zwierząt kopytnych [Wolf (Canis lupus L.) in Bydgoszcz Primeval Forest and its impact on the populations of wild ungulates], Infrastruktura i ekologia terenów wiejskich 2: 247-260.

Kondracki J., 2000, Geografia regionalna Polski [Regional geography of Poland], Wydawnictwo Naukowe PWN, Warszawa.

Musiani M., Okarma H. \& Jędrzejewski W., 1998, Speed and actual distances travelled by radiocollared wolves in Białowieża Primeval Forest (Poland), Acta Theriologica 43: 409-416.

Nowak S., 2013, Wielki powrót [The great return], Wiedza i życie 3 (940): 49-53.

Nowak S. \& Mysłajek R. W., 2000, Tropem wilka [Following the footsteps of the wolf], Stowarzyszenie dla Natury "Wilk", Godziszka.

Nowak S. \& Mysłajek R. W., 2011, Wilki na zachód od Wisły [Wolf on the West of the Vistula River], Stowarzyszenie dla Natury "Wilk", Twardorzeczka.

Patterson B., Quinn N. W. S., Becher E. F. \& Meier D. B., 2004, Estimating wolf densities in forested areas using network sampling of tracks in snow, Wildlife Society Bulletin, 32 (3): 938-947.

Sewerniak P., 2010, Wolves in the Torun Basin, Ecological Questions 13: 47-53.

Zub K., Theuerkauf J., Jędrzejewski W., Jędrzejewska B., Schmidt K. \& Kowalczyk R., 2003, Wolf pack territory marking in the Białowieża Primeval Forest (Poland), Behavior 140, Koninklijke Brill NV, Leiden: 635-648. 